
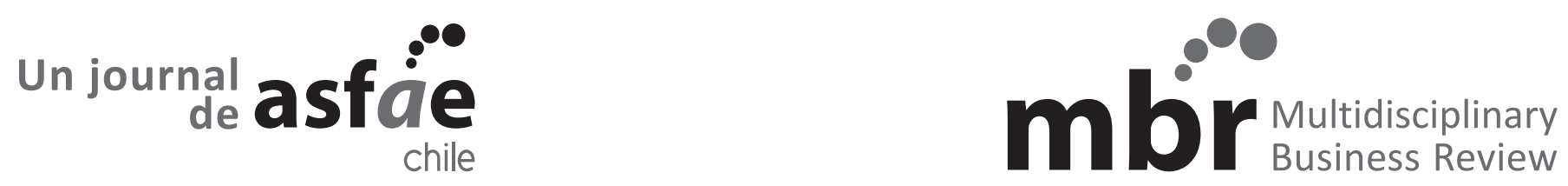

\title{
WHAT IS LOVE? EXPLORING THE MEANING OF BRAND LOVE AND ITS ROLE IN DETERMINING BRAND LOYALTY
}

\author{
¿QUÉ ES EL AMOR? EXPLORANDO EL SIGNIFICADO DEL AMOR POR LA MARCA \\ Y SU ROL EN LA DETERMINACIÓN DE LA LEALTAD A LA MARCA
}

\author{
Chantal Mahlke $\bullet$ Sarah Lahmeyer ${ }^{\mathrm{b}} \cdot$ Ellen Roemer $^{\mathrm{c}}$ \\ Classification: Empirical paper - research \\ Received: July 1, 2020 / Revised: September 2, 2020 / Accepted: September 7, 2020
}

\begin{abstract}
This paper measures brand love of smartphones in a specific cultural context. It assesses and compares the effects of brand love and satisfaction on brand loyalty and positive word-of-mouth. The authors use a qualitative approach to select and adapt a measurement scale of the brand love construct for Germany. They use a quantitative study to evaluate the relationships between brand love, satisfaction, brand loyalty and positive word-of-mouth for the case of smartphone brands. Brand love measurement needs to be adapted to the German context. Brand love has a higher impact than satisfaction on brand loyalty and positive word-of-mouth for smartphones. Brand love partly mediates the relationship between satisfaction and brand loyalty as well as positive word-of-mouth. The brand love construct has been tested in a specific cultural context, in this case, Germany. Scale development efforts have to be dedicated to the verification and/or adaptation of the construct to other cultural environments like Latin America. Practitioners should include the measurement of brand love in addition to satisfaction in order to predict brand loyalty. The adaptation of the brand love construct to a specific cultural context has been ignored in previous literature. The comparison of the direct effects of brand love and satisfaction as well as the indirect effects of brand love have been neglected so far.
\end{abstract}

Keywords: brand love, brand loyalty, culture, satisfaction, smartphone, word-of-mouth.

\section{Resumen}

Este artículo mide el amor por la marca de los teléfonos inteligentes en un contexto cultural específico. Evalúa y compara los efectos del amor y la satisfacción por la marca sobre la lealtad a la marca y el boca a boca positivo. Los autores utilizan un enfoque cualitativo para seleccionar y adaptar una escala de medición de la construcción del amor por la marca para Alemania. Utilizan un estudio cuantitativo para evaluar las relaciones entre el amor por la marca, la satisfacción, la lealtad a la marca y el boca a boca positivo para el caso de las marcas de teléfonos inteligentes. La medición del amor por la marca debe adaptarse al contexto alemán. El amor por la marca tiene un impacto mayor que la satisfacción en la lealtad a la marca y el boca a boca positivo para los teléfonos inteligentes. El amor por la marca media en parte la relación de satisfacción y lealtad a la marca, así como en el boca a boca positivo. La construcción del amor por la marca se ha probado en un contexto cultural específico, aquí Alemania. Los esfuerzos de desarrollo de la escala deben estar dedicados a la verificación y / o adaptación del constructo a otros entornos culturales como América Latina. Los profesionales deben incluir la medición del amor por la marca además de la satisfacción para

Siemens AG, Werner-von-Siemens-Straße 1, 80333 Munich, Germany, Chantal.Mahlke@gmx.de

Hochschule Ruhr West, Department of Business Administration and Economics, Duisburger Str. 100, 45479 Muelheim an der Ruhr, Germany; Sarah.Lahmeyer@stud.hs-ruhrwest.de

c Hochschule Ruhr West, Department of Business Administration and Economics, Duisburger Str. 100, 45479 Muelheim an der Ruhr, Germany; Ellen.Roemer@hs-ruhrwest.de 
predecir la lealtad a la marca. La adaptación del constructo amor por la marca a un contexto cultural específico ha sido ignorada anteriormente en la literatura. Hasta ahora se ha descuidado la comparación de los efectos directos del amor y la satisfacción por la marca, así como los efectos indirectos del amor por la marca.

Palabras clave: amor por la marca, lealtad a la marca, cultura, satisfacción, teléfono inteligente, boca a boca.

\section{Introduction}

In recent years, the role of emotions and the new phenomenon of brand love have gained increasing attention in marketing (e.g., Albert \& Merunka, 2013; Bagozzi, Batra, \& Ahuvia, 2017; Batra, Ahuvia, \& Bagozzi, 2012; Bergkvist \& Bech-Larsen, 2010; Carroll \& Ahuvia, 2006; Fetscherin, 2014; Gumparthi \& Patra, 2020; Junaid, Hussain, Basit, \& Hou, 2019; Kaufmann, Loureiro, \& Manarioti, 2016; Langner, Bruns, Fischer, \& Rossiter, 2016; Loureiro, Ruediger, \& Demetris, 2012; Machado, Vacas-de-Carvalho, Azar, André, \& dos Santos, 2019; Palusuk, Koles, \& Hasan, 2019; Pang, Tat, \& Peng, 2009; Rosado-Pinto, Loureiro, \& Bilro, 2020; Roy, Eshghi, \& Sarkar, 2013; Sarkar, Ponnam, \& Murthy, 2012; Wallace, Buil, \& de Chernatony, 2014). Consequently, marketing scholars have developed a plethora of measurement scales to assess brand love (see e.g., Albert, Merunka, \& Valette-Florence, 2009; Bagozzi et al., 2017; Batra et al., 2012; Carroll \& Ahuvia, 2006; Fetscherin, 2014; Junaid et al., 2019; Keh, Pang, \& Peng, 2007; Sarkar et al., 2012). Despite the research effort to develop different brand love scales, their validity has to be questioned; in particular, Rossiter (2012) criticized the scales' content validity. Moreover, face validity may become problematic (Netemeyer, Bearden, \& Sharma, 2003), when marketing researchers and practitioners intend to analyse brand love, but measurement scales have been developed in a different cultural context. From an intercultural perspective, the usage of the word "love" varies. For example, expressions of love are much higher in the US or in France in terms of frequency and intensity than in other cultures like Japan or Germany (Ting-Toomey, 1991). The question is, whether and to what extent existing brand love scales, which have been developed for one country, can be used in another country. Insights are missing regarding the measurement of brand love and its validity when applied to a specific cultural context.

In addition, it is surprising that practitioners in marketing management and marketing research still seem to ignore brand love and its well-researched impact on brand loyalty (Albert \& Merunka, 2013; Batra et al., 2012; Carroll \& Ahuvia, 2006; Kaufmann et al., 2016; Roy et al., 2013; Sarkar et al., 2012; Wallace et al., 2014). Brand love scales thus have been rarely applied in marketing practice. Instead, practitioners usually measure satisfaction and/or brand loyalty, for example, by assessing the net promotor score (NPS) (Reichheld, 2003). Often, satisfaction is used as a proxy for brand loyalty (Aksoy, 2013). For marketing practitioners, the question is whether they are missing out when measuring only satisfaction instead of brand love to predict brand loyalty.

Conversely, the role of satisfaction is ambiguous or even ignored in academic brand love research. For example, Batra et al. (2012) use attitude valence as a dimension within the brand love construct that shows some overlap with satisfaction, potentially resulting in construct proliferation (Shaffer, DeGeest, \& Li, 2016). Then, satisfaction becomes a part of brand love. Other authors ignore satisfaction in their investigations regarding antecedents and consequences of brand love (e.g., Albert \& Merunka, 2013; Bairrada, Coelho, \& Coelho, 2018; Bıçakcığlu, İpek, \& Bayraktaroğlu, 2018; Kaufmann et al., 2016), which means that the interplay of brand love with satisfaction and brand loyalty remains unclear.

This paper's aims are (1) to explore the meaning of brand love and to measure brand love in a specific cultural context (Germany) and (2) to investigate the role of brand love in comparison to satisfaction when determining brand loyalty and positive word-of-mouth.

This paper makes the following contributions. First, it provides a deeper understanding of the brand love construct and its measurement in a specific cultural context. Using a qualitative study, we show how a brand love scale can be selected and adapted to a German context. Special attention is dedicated towards discriminant validity in order to avoid overlaps with other related constructs. Second, it clarifies the relative importance of brand love and satisfaction when explaining brand loyalty and positive word-of-mouth based on empirical data relating to smartphone brands. It also provides evidence regarding how far brand love acts as a mediator in the relationship between satisfaction and brand loyalty or positive wordof-mouth.

The remainder of this paper is structured as follows. The next section provides the theoretical background of brand love and its measurement. We also derive hypotheses on the relationships between brand love, satisfaction, brand loyalty and positive word-of-mouth, thereby developing a theoretical framework. In Section 3, we conduct a qualitative study to select an appropriate brand 
love scale and to adapt the selected scale to the German context. In Section 4, we test the theoretical framework in a large-scale quantitative study. Sections 5 and 6 summarize and discuss the main results of the study. The paper closes with a summary as well as limitations and considerations for future research.

\section{Theoretical Background and Hypotheses}

\section{Brand Love}

The analysis of customers' emotional connections and ties to their brands as well as their emotional attachment to their loved products have led to the brand love concept as suggested by Carroll \& Ahuvia (2006) (Loureiro et al., 2012). Carroll \& Ahuvia (2006, p. 81) defined brand love as "the degree of passionate emotional attachment a satisfied consumer has for a particular trade name". They operationalized brand love as a unidimensional scale using ten items with five-point Likert-type scales. They developed their scale in an Anglo-American context.

Later, Keh et al. (2007), Albert et al. (2009), Batra et al. (2012) as well as Sarkar et al. (2012) developed more complex scales of brand love. Based on Keh et al. (2007), Pang et al. (2009) used three dimensions, i.e., brand intimacy, brand passion, and brand commitment to conceptualize brand love. Their scale was developed in a Chinese context. In 2009, Albert et al. (2009) introduced the brand love construct as a second-order construct consisting of "affection" and "passion". They developed their scale in France. In addition, the scale comprises dimensions that are otherwise conceptualized as separate constructs; e.g., brand commitment. Sarkar et al. (2012) conceptualized romantic brand love as brand passion containing four items. They developed their scale in India. Batra et al. (2012) conceptualized an even more complex higher-order factor model with seven core elements, i.e., selfbrand integration, passion-driven behaviours, positive emotional connection, long-term relationship, positive overall attitude valence, attitude certainty, and confidence, as well as anticipated separation distress. The scale was developed in the United States along with the scale by Bagozzi et al. (2017).

In the course of time, other related constructs emerged in the scholarly discussion strongly relating to brand love. For example, Thomson, MacInnis, \& Park (2005) investigated emotional attachment, which Albert et al. (2009) filed as "brand passion". Brand passion, in turn, is one dimension of their second-order brand love construct. Similarly, brand passion represents one dimension of brand love in the research by Keh et al. (2007) and Pang et al. (2009). The debate on feelings about a brand has finally led to publications focusing solely on brand passion (Albert, Merunka, \& Valette-Florence, 2013).

In sum, the brand love scale has evolved from onedimensional to very complex multi-dimensional scales in which brand passion has either been treated as one dimension or has been used as a synonym for brand love (Fetscherin, 2014). Therefore, confusion may exist among academics and practitioners in terms of how to conceptualize brand love (Junaid et al., 2019; Palusuk et al., 2019) and how to measure the construct in a practical manner. In addition, Rossiter (2012) already hinted at content validity problems regarding the brand love scales, which he contrasted with the construct of "brand liking". He also hinted at different meanings of "love" in the context of brands and products. Therefore, we suggest that the meaning of love also differs across cultural environments (see similar Drennan et al., 2015; Ting-Toomey, 1991) and that brand love measurement scales need careful selection, as well as potential revision and adaptation to ensure content validity (Rossiter, 2012). Therefore, we decided to conduct a qualitative study to explore the meaning in Germany and to select an appropriate scale (see Section 3).

\section{Satisfaction}

In contrast to brand love, the measurement of satisfaction has a long tradition in marketing theory and practice. Satisfaction has become one of the most popular constructs in marketing theory and practice resulting in large-scale customer satisfaction surveys or indexes such as the Swedish Customer Satisfaction Barometer (SCSB) (Fornell, 1992) or the American Customer Satisfaction Index (ACSI) (Fornell, Johnson, Anderson, Cha, \& Bryant, 1996). Satisfaction has been discussed in marketing research as a strong antecedent of brand loyalty (e.g., Agustin \& Singh, 2005; Bennett, Härtel, \& McCollKennedy, 2005; Bolton, 1998; Ganesan, 1994; Oliver, 1980). According to Oliver (1997, p. 13, emphasis in original) "Satisfaction is the consumer's fulfilment response. It is a judgment that a product/service feature, or the product or service itself, provided (or is providing) a pleasurable level of consumption-related fulfilment, including levels of under- or overfulfilment".

Although the relationship between satisfaction and loyalty has a long research tradition in marketing (e.g., Anderson \& Sullivan, 1993; Dick \& Basu, 1994; Fornell et al., 1996; Oliver, 1980), satisfaction plays an ambiguous role in brand love research. From one perspective, satisfaction is a part of the brand love construct. For example, Batra et al. (2012) use components of brand love that show some overlap with 
satisfaction (e.g., "attitude valence" in Batra et al. 2012) and loyalty (e.g., "long-term relationship" in Batra et al. 2012). From another perspective, satisfaction and brand love are separate constructs. Accordingly, Carroll \& Ahuvia (2006, p. 81) clearly state that "brand love and satisfaction are different constructs". They see mainly four differences between the two constructs:

Table 1. Difference between satisfaction and brand love

\begin{tabular}{lll}
\hline No. & \multicolumn{1}{c}{ Satisfaction } & \multicolumn{1}{c}{ Brand Love } \\
\hline 1 & cognitive judgement & affective focus \\
2 & transaction-specific & long term relationship \\
3 & expectancy - disconfirmation & -- \\
4 & $\begin{array}{l}\text { No integration into a consumer's } \\
\text { identity }\end{array}$ & $\begin{array}{l}\text { willingness to declare brand love; } \\
\text { integration into a consumer's } \\
\text { identity }\end{array}$ \\
\hline
\end{tabular}

Source: Based on Carroll and Ahuvia (2006).

Carroll \& Ahuvia (2006) have investigated brand love for packaged goods with which consumers were already satisfied. Therefore, satisfaction is seen as a precondition for brand love (Christino, Silva, Moura, \& Fonseca, 2020; Roy et al., 2013). Similarly, Thomson et al. (2005) argue that satisfaction is different from brand love (they refer to brand love as "emotional attachment"). They state: "satisfaction might provide a basis for emotional attachment" (Thomson et al., 2005, p. 79). From this perspective, satisfaction is an antecedent of brand love. Consequently, we suggest $\mathrm{H} 1$.

H1: Satisfaction has a positive effect on brand love.

In line with prior research on the satisfaction - brand loyalty nexus (e.g., Anderson \& Sullivan, 1993; Dick \& Basu, 1994; Fornell et al., 1996; Oliver, 1980), we suggest the following hypothesis:

H2: Satisfaction has a positive effect on brand loyalty.

\section{Brand Loyalty and Positive Word-Of-Mouth}

Brand loyalty is important for managers in marketing practice since it is a predictor for consumers' repurchase behaviour; in turn, securing a company's future returns (Oliver, 1999, 2014). There is a plethora of conceptions regarding brand loyalty (for an overview, see e.g., Knox \& Walker, 2001). In this paper, we refer to the behavioural aspects of loyalty (i.e., repeat purchase behaviour; repurchase intention) to differentiate it from the constructs of satisfaction and brand love (Dick \& Basu, 1994; Yim \& Kannan, 1999). Therefore, we use Oliver's definition of brand loyalty $(1997,1999)$ who defines brand loyalty as "a deeply held commitment to rebuy or repatronize a preferred product/service consistently in the future, thereby causing repetitive same-brand or same brand-set purchasing, despite situational influences and marketing efforts having the potential to cause switching behaviour." (Oliver, 1999, p. 34, emphasis in original).

This behavioural conception of loyalty is in line with the loyalty concepts used in prior brand love research (Batra et al., 2012; Carroll \& Ahuvia, 2006; Kaufmann et al., 2016; Roy et al., 2013; Sarkar et al., 2012). Prior research suggested a positive relationship between brand love and brand loyalty (Bairrada et al., 2018; Batra et al., 2012; Bergkvist \& Bech-Larsen, 2010; Bıçakcığlu et al., 2018; Carroll \& Ahuvia, 2006; Fetscherin, 2014; Kaufmann et al., 2016; Roy et al., 2013; Sarkar et al., 2012). Therefore, we propose:

H3: Brand love has a positive impact on brand loyalty.

In the context of brand love, Carroll \& Ahuvia (2006) found a positive relationship between brand love and positive word-of mouth. This relationship has been confirmed by Albert et al. (2009), Albert \& Merunka (2013), Bairrada et al. (2018), Batra et al. (2012), Bıçakcıŏlu et al. (2018), Christino et al. (2020), Fetscherin (2014), Sarkar et al. (2012) and Wallace et al. (2014). Consequently, we suggest the following hypothesis.

H4: Brand love has a positive impact on positive word-of-mouth.

Roy et al. (2013, p. 330) also indicated that brand love mediates the relationship between satisfaction and positive word-of-mouth. However, they did not provide empirical evidence for this relationship. In the same manner, we expect brand love to mediate the relationship between satisfaction and brand loyalty. Therefore, we suggest $\mathrm{H} 5$ and $\mathrm{H} 6$.

H5: Brand love mediates the relationship between satisfaction and brand loyalty.

H6: Brand love mediates the relationship between satisfaction and positive word-of-mouth.

Finally, researchers have argued that satisfaction has a positive impact on positive word-of-mouth or postpurchase communications (Fornell, 1992; Oliver, 1980). Therefore, we also hypothesize that:

H7: Satisfaction has a positive effect on positive word-of-mouth.

Figure 1 visualizes hypotheses $\mathrm{H} 1$ to $\mathrm{H} 7$ in a theoretical framework. Solid lines indicate direct effects (H1 to H4 and H7). The dashed lines represent indirect effects relating to the mediating effects of brand love as hypothesized in $\mathrm{H} 5$ and $\mathrm{H} 6$. 
Figure 1. Theoretical Framework

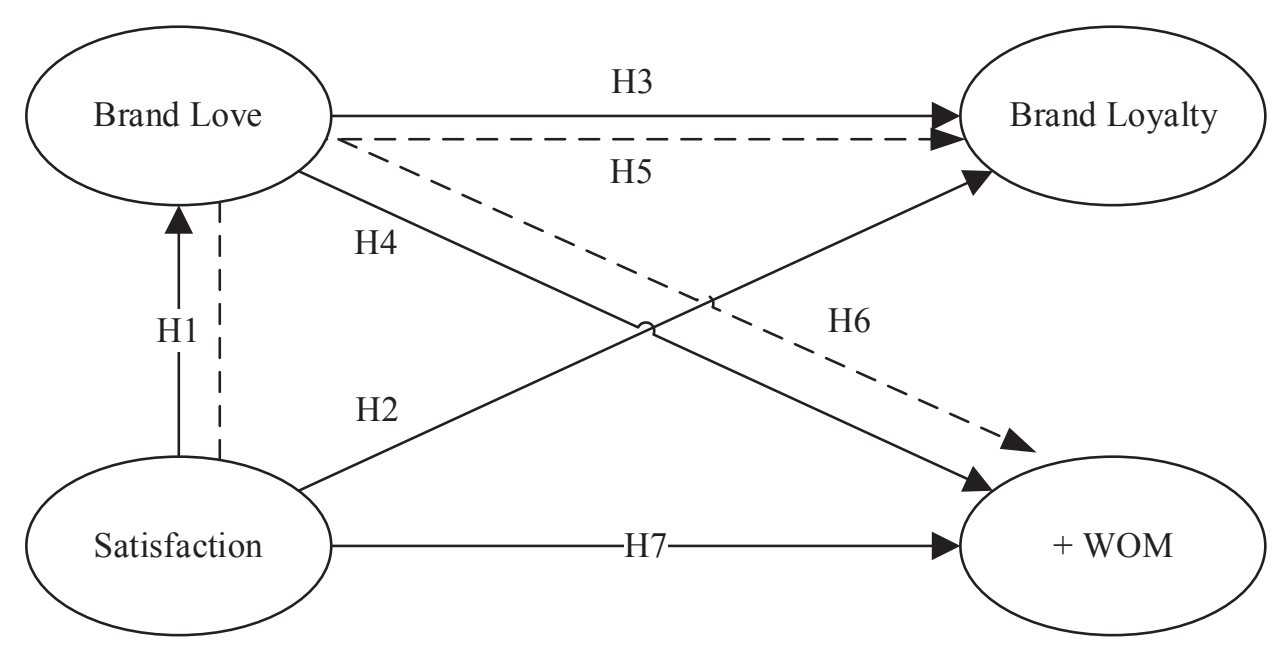

\section{Qualitative Study}

Rossiter (2012) found in his study in Germany that only very few respondents deliberately indicated the stage of brand love (17\% for laundry detergents, $18 \%$ for coffee, $26 \%$ for computers, and $45 \%$ for fashion clothing) instead of liking a brand, feeling neutral or disliking a brand. To avoid validity problems when using a previously developed scale in Germany, we conducted a qualitative study. A recent literature review on the brand love construct revealed that only few papers have used a qualitative research design so far (Gumparthi \& Patra, 2020). Also Bagozzi et al. (2017) called for more qualitative studies in brand love research.

Our aim of the qualitative study was to explore the meaning of brand love in Germany to ensure content validity. The question was whether we could use one of the existing scales and its items reflecting the German understanding of brand love in our study. In this way, face validity should be accommodated. Another aim was to investigate the relationship of brand love with other behavioural constructs, such as brand loyalty, ensuring discriminant and nomological validity.

We used problem-centred expert interviews to revise and to potentially include further elements of the brand love construct, which might not have been mentioned in the literature so far (Witzel, 2000; Witzel \& Reiter, 2012). We created an interview guide with nine openended questions to explore the nature of brand love in a new cultural context. However, the interview guide purely served as an orientation due to the open nature of problem-centred interviews (Witzel, 2000; Witzel \& Reiter, 2012). Our aim was a diversified and unbiased feedback on brand love and brand loyalty. According to Witzel (2000, p. 5), we chose our respondents as "experts of their orientations and actions". For problem-centred interviewing, respondents' thoughts and opinions are central. Therefore, a trust relationship between the interviewer and respondents is a prerequisite for gaining deep and relevant insights. We selected our experts from the direct environment of the authors, thus guaranteeing a trust relationship and encouraging respondents to speak frankly (Witzel, 2000). In addition to trust, we paid attention to gender (five female and two male interviewees) and age (24 to 77 years old). The expert interviews were conducted in German. We instructed the experts regarding the aim of the interview and legal aspects beforehand. A definition of brand love was deliberately not provided and the limitation to a specific product category was not mentioned (Witzel, 2000). Table 1 provides an overview of the qualitative sample regarding gender and age.

The interviews were conducted by telephone, recorded and transcribed. We stopped interviewing as soon as information redundancy occurred. We conducted seven interviews with a duration of up to 42 minutes.

Surprisingly, only two out of the seven experts (A and F) deliberately stated that they love brands. They highlighted the brand's potential to differentiate itself from the competition. For example, expert A stated (02:44)

Table 2. Qualitative Study Sample

\begin{tabular}{ccc}
\hline Expert & Gender & Age \\
\hline A & Female & 26 \\
B & Female & 77 \\
C & Female & 24 \\
D & Male & 29 \\
E & Male & 61 \\
F & Female & 32 \\
G & Female & 50 \\
\hline
\end{tabular}


"If somebody says, here is brand $\mathrm{X}$ and places brand $\mathrm{Y}$ next to brand X, I would immediately choose brand X over brand Y." Expert F specified (00:32) "I am actually in love with brand $\mathrm{X}$. Yes, you can say that I would not buy anything else and I would not let anybody talk me into another brand."

$D$ and $G$ interpreted brand love as their preference for a specific brand. They mentioned brands, that they have been using for a long period of time due to habit or products that previously improved their own self-image. However, they had difficulties to differentiate brand love and brand loyalty. Only upon explicit request, D assigned his smartphone to brand love since it offered the best technology and he would defend the brand against others. $\mathrm{G}$ was unable to draw a clear line between love and loyalty at first. However, when discussing her coffee and coffee filter brand, it quickly became clear that she was very enthusiastic about these brands and tried to convince others of them, indicating that word-of-mouth plays a role in the brand love - brand loyalty nexus.

The three remaining interviewees, $\mathrm{B}, \mathrm{C}$ and $\mathrm{E}$, showed no tendencies towards brand love. Instead, they expressed strong loyalty based on good experiences made with the brand in the past. While $\mathrm{B}$ and $\mathrm{C}$ bought their brands out of habit and necessity, E had to be continuously convinced of this brand.

In line with Rossiter's results (2012), we found that only few respondents deliberately expressed the notion of love regarding brands in our qualitative study. Our interviewees reported preferences over other products or brands as their understanding of brand love instead of strong feelings for a brand as theorized in the extant literature. They also highlighted the comparative nature of the construct, since they compared their loved brand with competing brands. We concluded that we had to carefully select and potentially revise an existing brand love scale to reflect the German understanding of brand love in the measurement scale, thus ensuring content and face validity.

We therefore examined the different brand love scales (Albert et al., 2009; Batra et al., 2012; Keh et al., 2007; Sarkar et al., 2012; Thomson et al., 2005). We looked for scales with items relating to the strong preference of brands in comparison to competing brands as mentioned in the qualitative study. This was best expressed in the brand passion component of the brand love scale developed by Keh et al. (2007) and used by Pang et al. (2009). We then used quotations from the qualitative study regarding the understanding of brand love and matched them with the scale items to adapt the scale (see Table 3).

In our qualitative study, we also found that the respondents had difficulties in differentiating between brand love and brand loyalty. In order to treat brand love and brand loyalty as separate constructs in our model and thus to ensure discriminant validity between the constructs, special attention will be paid to discriminant validity assessment in our quantitative study.

Table 3. Measurement Items

\begin{tabular}{|c|c|c|}
\hline Code & Scale & Expert, Time Marker, Item \\
\hline \multirow{3}{*}{$8 \mathrm{~d}$} & adapted & I would rather own this brand than any other smartphone brand. \\
\hline & & $\begin{array}{l}\text { A } \\
02: 44 \text { If somebody says, here is brand } \mathrm{X} \text { and places brand } \mathrm{Y} \text { next to brand } \mathrm{X} \text {, I would immediately choose brand } \mathrm{X} \text { over brand } \mathrm{Y} \text {. }\end{array}$ \\
\hline & & $\begin{array}{l}\text { B } \\
00: 32 \text { If I have two similar things [products], I would choose the brand that I am more inclined towards. }\end{array}$ \\
\hline \multirow[t]{3}{*}{$8 \mathrm{e}$} & original & I cannot imagine another brand of the same product making me as happy as this brand. \\
\hline & adapted & I cannot imagine another smartphone brand making me as happy as this brand. \\
\hline & & $\begin{array}{l}\text { A } 18: 01 \text { When I buy something [product or brand] which is awesome, I am happy for about one year. } \\
\text { 18 }\end{array}$ \\
\hline \multirow[t]{3}{*}{$8 \mathrm{~g}$} & original & I have the impulse to buy it at the sight of the brand. \\
\hline & adapted & When I see this smartphone brand next to other smartphone brands, I have the impulse to buy it straight away. \\
\hline & & $\begin{array}{l}\text { E } \\
00: 30\end{array}$ "I understand brand love as buying a product of a particular brand straight away without comparing it to other competitive products." \\
\hline
\end{tabular}

Source: Adaptation of Keh et al.'s (2007). 


\section{Quantitative Study}

\section{Questionnaire Development}

Based on the insights from the qualitative study and the literature review, we developed a standardized questionnaire to investigate the suggested framework. The questionnaire was in German. All items were translated from English to German. For the translation of most of the items, we referred to a German translation based on Giering (2000). The remaining items were translated from English into German using the back-translation method (Usunier, 1998). We used seven-point Likert-type scales (ranging from "strongly agree" (1) to "strongly disagree" (7)) to measure the items of the different constructs. The questionnaire was conducted online to collect the data. We used convenience sampling and shared the link via e-mail and social media platforms with students, colleagues and friends, thus creating "a sample from the population that is close at hand" (Sarstedt \& Mooi, 2019). We encouraged addressees to further share the link. The data was anonymously processed.

We focused our quantitative study on the product category and brand of smartphones, since we found in the interviews that respondents would show strong relationships with their smartphones and the related smartphone brand (see similar Christino et al., 2020; Junaid et al., 2019; Van Deursen, Bolle, Hegner, \& Kommers, 2015; Yeh, Wang, \& Yieh, 2016). In addition, smartphones are products with hedonic value components, so an investigation into brand love seems appropriate (Lin, Huang, \& Hsu, 2015).

\section{Measures}

To measure brand love, we used the adapted Keh et al. (2007) scale. We operationalized brand satisfaction based on the 12-item scale on overall customer satisfaction measurement by Richard L. Oliver (Oliver, 1980, 1997, 2014). We adjusted the items to the research context of brand satisfaction as suggested by Oliver $(1997,2014)$. Reverse scale items had to be deleted due to insufficient factor loadings (see similar to Wallace et al., 2014).

\section{Sample}

Overall, 186 respondents completed the questionnaire. No outliers were detected. Two cases had to be deleted due to too many missing values. The final dataset consisted of 184 cases. Respondents' age ranged from 16 to 70 with a mean of 32.7 years. 112 respondents were female, 72 were male. We used PLS path modelling to examine the causal relationships between the constructs of brand love, satisfaction, loyalty, and positive word-of-mouth. To determine the minimum sample size, Hair, Hult, Ringle, \& Sarstedt (2017) propose using power analyses (Cohen, 1992). For a statistical power of $80 \%$, a significance level of $5 \%$, a maximum of three arrows pointing at a construct, and a minimum $\mathrm{R}^{2}$ of 0.25 in the endogenous construct, at least 37 observations are needed. Our sample size of 184 cases lies well above this threshold so that PLS can be used.

\section{Results}

Using the software package SmartPLS 3 (Ringle, Wende, \& Becker, 2015), we modelled the four behavioural concepts as reflective measurement models (Benitez, Henseler, Castillo, \& Schuberth, 2020). We used the path weighting scheme for the structural model with a maximum of 1,000 iterations and a stop criterion of $10^{-7}$ to estimate the PLS path models (Hair et al., 2017).

We used composite reliability (CR), average variance extracted (AVE), as well as indicator reliability, using the constructs' factor loadings and their significances to assess the measurement models (Benitez et al., 2020; Hair et al., 2017; Henseler, Ringle, \& Sinkovics, 2009). One item in the adapted brand love scale had to be dropped due to insufficient factor loadings ( 0.489 for item $8 f, p=0.106$, n.s.).

To assess discriminant validity, we used the Heterotrait-Monotrait (HTMT) criterion (Henseler, Ringle, \& Sarstedt, 2015) to ensure that the constructs are significantly different from each other. For our model, the HTMT criterion is significantly smaller than 1 or 0.9 respectively (Henseler et al., 2015; Voorhees, Brady, Calantone, \& Ramirez, 2016). In addition, the one-sided $95 \%$ confidence interval does not include the value 1 , so that it is significantly different from 1 (Benitez et al., 2020).

To evaluate the structural model, we assessed the collinearity of the predictor constructs, path coefficients, $\mathrm{R}^{2}$, as well as effect sizes (Hair et al., 2017). Collinearity was not an issue regarding the predictor constructs, since the variance inflation factors (VIF) were below 5. The paths coefficients of the direct effects were significant as well as the two mediating effects. Also $\mathrm{R}^{2}$ ranged from moderate levels 0.382 (for brand love) to almost substantial levels ( 0.577 for positive word-of-mouth and 0.613 for brand loyalty) (Chin, 1998). Effect sizes $\mathrm{f}^{2}$ ranged from small to large levels (Cohen, 1988). Figure 2 visualizes the $\mathrm{R}^{2}$ as well as the path coefficients of the direct (the solid line) and indirect effects (the dashed line).

\section{Discussion}

We found support for hypotheses $\mathrm{H} 1$ to $\mathrm{H} 4$ and $\mathrm{H} 7$, since all direct effects are significant in the model. This is not 
Table 4. Assessment of the Quality of Measurement

\begin{tabular}{|c|c|c|c|c|}
\hline & Source / Item(s) & $\mathbf{C R}$ & AVE & Loading \\
\hline $8 \mathrm{~d}$ & \multicolumn{3}{|l|}{ I would rather own this brand than any other smartphone brand. } & $0.881 * * *$ \\
\hline $8 \mathrm{e}$ & \multicolumn{3}{|l|}{ I cannot imagine another smartphone brand making me as happy as this brand. } & $0.809 * * *$ \\
\hline $8 g$ & \multicolumn{3}{|c|}{ When I see this smartphone brand next to other smartphone brands, I have the impulse to buy it straight away. } & $0.774 * * *$ \\
\hline $9 \mathrm{a}$ & It is very likely that I will buy the same smartphone brand next time. & & & $0.884 * * *$ \\
\hline $9 \mathrm{~b}$ & I do not intend to buy another smartphone brand. (RC) & & & $0.899 * * *$ \\
\hline $9 \mathrm{c}$ & I intend to be loyal to the brand. & & & $0.927 * * *$ \\
\hline $9 \mathrm{~d}$ & I do not think that I will try another smartphone brand next time. (RC) & & & $0.858 * * *$ \\
\hline $9 \mathrm{f}$ & I spread the good word-of-mouth about this brand. & & & $0.912 * * *$ \\
\hline $9 \mathrm{~g}$ & I intend to recommend this brand to other people. & & & $0.932 * * *$ \\
\hline \multicolumn{2}{|c|}{ Satisfaction adapted from Oliver $(1980,1997,2014)$} & 0.932 & 0.734 & \\
\hline $10 \mathrm{a}$ & Overall, I am satisfied with this smartphone brand. & & & $0.894 * * *$ \\
\hline $10 \mathrm{c}$ & This smartphone brand has worked out as well as I thought it would. & & & $0.867 * * *$ \\
\hline $10 \mathrm{e}$ & My choice to buy this smartphone brand was a wise one. & & & $0.791 * * *$ \\
\hline $10 \mathrm{f}$ & This is one of the best smartphone brands I could have bought. & & & $0.881 * * *$ \\
\hline $10 \mathrm{~g}$ & This smartphone brand is exactly what I need. & & & $0.848 * * *$ \\
\hline
\end{tabular}

$\mathrm{RC}=$ Reverse Coding

surprising since they are well documented in the literature. Our intention was to assess the path coefficients relative to one another and compare the strengths of the effects of satisfaction with brand love. First, satisfaction has significant impacts on both brand loyalty (H2) and on positive word-of-mouth (H7). However, the direct effects of brand love on brand loyalty (H3) and on positive word-of-mouth (H4) are much larger than those of satisfaction. Therefore, brand love has greater effects on brand loyalty and on positive word-of-mouth than satisfaction, and is thus more important in determining the two.

Second, to analyse brand love as a mediator in the relationships between satisfaction and loyalty, as well as between satisfaction and positive word-of-mouth, we checked the indirect and the direct effects. The indirect effects (H5 and H6) are significant as well as the

Figure 2. Structural Model Results

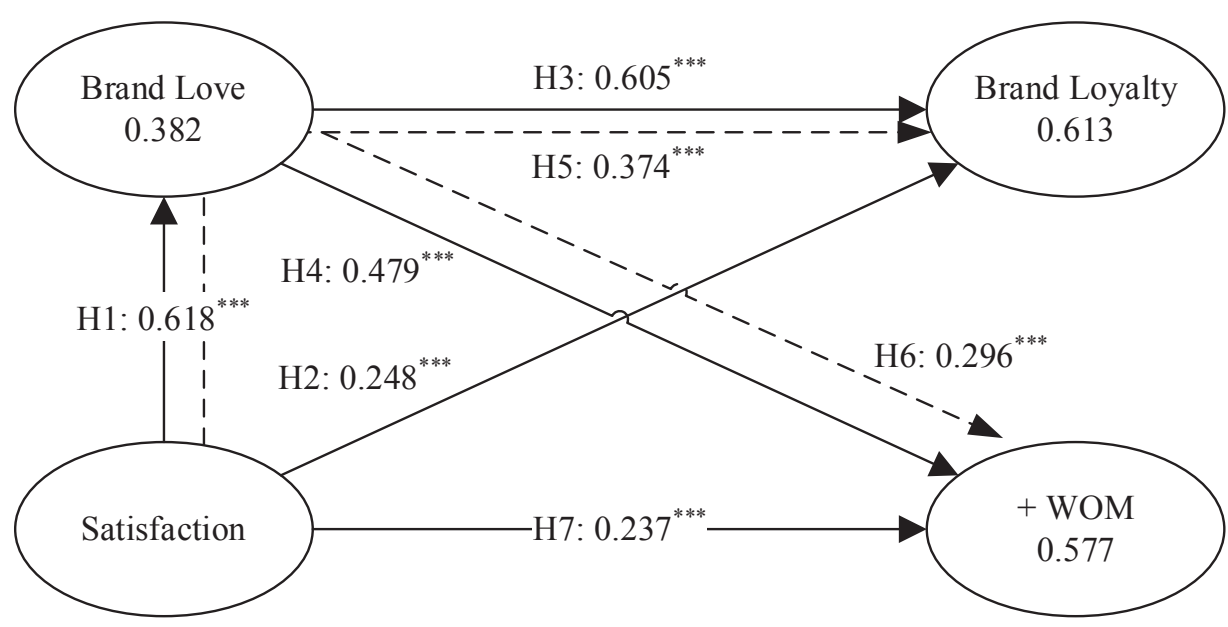


direct effects (H2 and H7). All effects are positive. Brand love thus partly mediates the relationship between satisfaction and brand loyalty (H5), as well as the relationship between satisfaction and positive word-of-mouth (H6) (Zhao, Lynch Jr, \& Chen, 2010). This means that the impact of satisfaction is higher when brand love is present. Consequently, even though satisfaction has weaker direct effects than brand love on brand loyalty and positive word-of-mouth, satisfaction and its impacts become stronger in the presence of brand love.

\section{Implications for Theory}

Researchers should carefully review the brand love construct and its related measurement items before applying it to a specific cultural context. This can be done by carrying out a qualitative pre-study on target consumers in order to identify the relevant and most suitable measurement scales. A team of market researchers should then select an existing scale that has already been validated and adapt it to the specific cultural context, to which it should be applied. Original brand love scales differ significantly between each other regarding their conceptualizations and items used (Junaid et al., 2019; Palusuk et al., 2019). Therefore, the question is which scale is most suitable and most valid in a particular cultural context. Items may not be transferrable to a new cultural context, therefore items should be revised, dropped or extended. This can be achieved in qualitative studies and adaptations as presented in this paper for a specific cultural context or country.

When having selected a specific brand love concept from the large variety of concepts, attention should be paid regarding potential overlaps between constructs such as satisfaction, brand love and brand loyalty. In order to increase discriminant validity and to avoid construct proliferation, the team of market research experts should carefully examine brand love scales and select the most suitable scale for a specific cultural context and simultaneously avoid overlaps with relating constructs. Insights from qualitative studies may help here to differentiate between and to sharpen the respective concepts. These can be conducted together with the aforementioned studies to ensure content validity (Rossiter, 2011a, b). Increased attention should also be paid to the assessment of heuristic and inference testing regarding discriminant validity (Franke \& Sarstedt, 2019; Henseler et al., 2015; Voorhees et al., 2016) when brand love is studied together with similar constructs like brand loyalty or brand commitment.

The role of brand love as a mediator should be explored in more depth in academic brand love research. A lot of studies focus on the direct effects of brand love without carefully analysing the indirect effects between antecedents and consequences (exceptions are e.g., Albert \& Merunka, 2013; Carroll \& Ahuvia, 2006; Machado et al., 2019) Our study has shown that brand love indeed partly mediates the relationship between satisfaction and brand loyalty as well as the relationship between satisfaction and positive word-of-mouth. These indirect effects are also relevant to marketing managers in business practice (see below).

\section{Implications for Management Practice}

Our results show that brand love is a stronger predictor of brand loyalty and positive word-ofmouth than satisfaction. This has important implications for marketing management practice. Traditionally, marketing research practitioners measure satisfaction and/or loyalty to predict their brand's or product's success. However, our research shows that they could be missing out when ignoring emotional concepts such as brand love in their measurements. Consequently, managers and market researchers should shift away from the more rational construct of satisfaction towards the more affective constructs such as brand love. It is surprising that measuring satisfaction has become a standard measurement instrument in market research practice, whereas other constructs are much more powerful in predicting brand loyalty and positive word-of-mouth, but are rarely used. Especially, market research for hedonic products should include the measurement of brand love at least in addition to satisfaction measures. In turn, predicting brand loyalty is essential for management.

It is necessary that the marketing researchers provide practitioners with scales that are both valid for a specific cultural context and, at the same time, easy to apply in management practice (such as the aforementioned Net Promoter Score). Complex scales with a multitude of dimensions and items (e.g., Batra et al., 2012) are unlikely to find high acceptance among marketing practitioners (Bagozzi et al., 2017). Therefore, the challenge will be to adapt existing scales to a cultural context and simultaneously provide practicable scales for marketing management practice. Tight collaborations between companies and universities may help to cope with this challenge.

In line with the prior recommendation, it is important for management practice to learn about the mediating effects of brand love. When brand love is present, satisfaction has an even higher impact on brand loyalty and positive wordof-mouth. In contrast, when brand love is missing this may have deteriorating effects on brand loyalty and positive word-of-mouth. Therefore, it is even more vital that brand 
love is actually measured in marketing research practice, ideally in combination with satisfaction.

\section{Conclusions, Limitations and Future Research}

The aim of this paper was to explore the meaning of brand love in a specific cultural context and its role, compared to satisfaction, on brand loyalty and positive word-of-mouth. We found that the understanding of the brand love construct may vary in different countries. Therefore, the most appropriate brand love measurement scale has to be selected, revised and potentially adapted to specific cultural contexts. The focus of this study was on Germany, which is culturally different from the US, France or India, where most of the brand love scales have been developed. Further research effort should be dedicated to the development and adaptation of the brand love scales to different cultural contexts, in order to ensure validity of the scales. Special attention should be dedicated to content validity and discriminant validity issues.

Furthermore, the more rational construct of satisfaction is still important for management practice, but only as a precondition for brand love, especially for products with hedonic elements. Instead, brand love is much more powerful than satisfaction in explaining brand loyalty and positive word-of-mouth and thus should be used in market research practice.

To assess the role of brand love in connection with satisfaction and loyalty, cross-cultural studies would be interesting in order to compare the levels of the constructs and their impacts on a nomological framework. Furthermore, our research is limited to the case of smartphones. Future studies should include other product categories in order to identify differences between the product categories, as well. Finally, our sample was relatively small. In addition, it was based on a convenience sampling method, resulting in a lack of representativeness. A larger scale and representative sample could help to improve our understanding of brand love and its interplay with satisfaction and brand loyalty.

\section{References}

Agustin, C., \& Singh, J. (2005). Curvilinear effects of consumer loyalty determinants in relational exchanges. Journal of Marketing Research, 42(1), 96-108.

Aksoy, L. (2013). How do you measure what you can't define? The current state of loyalty measurement and management. Journal of Service Management, 24(4), 356-381.

Albert, N., \& Merunka, D. (2013). The role of brand love in consumer-brand relationships. Journal of Consumer Marketing, 30(3), 258-266.
Albert, N., Merunka, D., \& Valette-Florence, P. (2009). The feeling of love toward a brand: Concept and measurement. Advances in Consumer Research, 36, 300307.

Albert, N., Merunka, D., \& Valette-Florence, P. (2013). Brand passion: Antecedents and consequences. Journal of Business Research, 66(7), 904-909.

Anderson, E. W., \& Sullivan, M. W. (1993). The antecedents and consequences of customer satisfaction for firms. Marketing Science, 12(2), 125-143.

Bagozzi, R. P., Batra, R., \& Ahuvia, A. (2017). Brand love: Development and validation of a practical scale. Marketing Letters, 28(1), 1-14.

Bairrada, C. M., Coelho, F., \& Coelho, A. (2018). Antecedents and outcomes of brand love: Utilitarian and symbolic brand qualities. European Journal of Marketing, 52(3/4), 656-682.

Batra, R., Ahuvia, A., \& Bagozzi, R. P. (2012). Brand love. Journal of Marketing, 76(2), 1-16.

Benitez, J., Henseler, J., Castillo, A., \& Schuberth, F. (2020). How to perform and report an impactful analysis using partial least squares: Guidelines for confirmatory and explanatory IS research. Information \& Management, 57(2), 1-16.

Bennett, R., Härtel, C. E., \& McColl-Kennedy, J. R. (2005). Experience as a moderator of involvement and satisfaction on brand loyalty in a business-to-business setting 02-314R. Industrial Marketing Management, 34(1), 97-107.

Bergkvist, L., \& Bech-Larsen, T. (2010). Two studies of consequences and actionable antecedents of brand love. Journal of Brand Management, 17(7), 504-518.

Bıçakcığlu, N., İpek, İ., \& Bayraktaroğlu, G. (2018). Antecedents and outcomes of brand love: The mediating role of brand loyalty. Journal of Marketing Communications, 24(8), 863-877.

Bolton, R. N. (1998). A dynamic model of the duration of the customer's relationship with a continuous service provider: The role of satisfaction. Marketing Science, 17(1), 45-65.

Carroll, B. A., \& Ahuvia, A. C. (2006). Some antecedents and outcomes of brand love. Marketing Letters, 17(2), 79-89.

Chin, W. W. (1998). The partial least squares approach to structural equation modeling. Modern Methods for Business Research, 295(2), 295-336.

Christino, J., Silva, T., Moura, L. R., \& Fonseca, L. H. (2020). Antecedents and consequents of brand love in the smartphone market: An extended study of the impact of switching cost. Journal of Promotion Management, 26(3), 301-321. 
Cohen, J. (1988). Statistical power analysis for the behavioral sciences. Abingdon, England: Routledge.

Cohen, J. (1992). A power primer. Psychological Bulletin, $112(1), 155-519$.

Dick, A. S., \& Basu, K. (1994). Customer loyalty: Toward an integrated conceptual framework. Journal of the Academy of Marketing Science, 22(2), 99-113.

Drennan, J., Bianchi, C., Cacho-Elizondo, S., Louriero, S., Guibert, N., \& Proud, W. (2015). Examining the role of wine brand love on brand loyalty: A multi-country comparison. International Journal of Hospitality Management, 49, 47-55.

Fetscherin, M. (2014). What type of relationship do we have with loved brands? Journal of Consumer Marketing, 31(6/7), 430-440.

Fornell, C. (1992). A national customer satisfaction barometer: The Swedish experience. The Journal of Marketing, 56(1), 6-21.

Fornell, C., Johnson, M. D., Anderson, E. W., Cha, J., \& Bryant, B. E. (1996). The American customer satisfaction index: Nature, purpose, and findings. The Journal of Marketing, 60(4), 7-18.

Franke, G., \& Sarstedt, M. (2019). Heuristics versus statistics in discriminant validity testing: A comparison of four procedures. Internet Research, 29(3), 430-447.

Ganesan, S. (1994). Determinants of long-term orientation in buyer-seller relationships. The Journal of Marketing, 58(2), 1-19.

Giering, A. (2000). Der Zusammenhang zwischen Kundenzufriedenheit und Kundenloyalität: Eine Untersuchung moderierender Effekte. Wiesbaden: Dt. Univ.-Verlag.

Gumparthi, V. P., \& Patra, S. (2020). The phenomenon of brand love: A systematic literature review. Journal of Relationship Marketing, 19(2), 93-132.

Hair, J. F., Hult, G. T. M., Ringle, C., \& Sarstedt, M. (2017). A primer on partial least squares structural equation modeling (PLS-SEM) (Second Edition ed.). Los Angeles: SAGE Publications.

Henseler, J., Ringle, C. M., \& Sarstedt, M. (2015). A new criterion for assessing discriminant validity in variance-based structural equation modeling. Journal of the Academy of Marketing Science, 43(1), 115-135.

Henseler, J., Ringle, C. M., \& Sinkovics, R. R. (2009). The use of partial least squares path modeling in international marketing. Advances in International Marketing, 20, 227-319.

Junaid, M., Hussain, K., Basit, A., \& Hou, F. (2019). Nature of brand love: Examining its variable effect on engagement and well-being. Journal of Brand Management, 27, 284-299
Kaufmann, H. R., Loureiro, S. M. C., \& Manarioti, A. (2016). Exploring behavioural branding, brand love and brand co-creation. Journal of Product \& Brand Management, 25(6), 516-526.

Keh, H. T., Pang, J., \& Peng, S. (2007). Understanding and measuring brand love. Paper presented at the Society for Consumer Psychology Conference Proceedings, Santa Monica.

Knox, S., \& Walker, D. (2001). Measuring and managing brand loyalty. Journal of Strategic Marketing, 9(2), 111-128.

Langner, T., Bruns, D., Fischer, A., \& Rossiter, J. R. (2016). Falling in love with brands: A dynamic analysis of the trajectories of brand love. Marketing Letters, 27(1), 15-26.

Lin, T.C., Huang, S.L., \& Hsu, C.J. (2015). A dual-factor model of loyalty to IT product: The case of smartphones. International Journal of Information Management, 35(2), 215-228.

Loureiro, S. M. C., Ruediger, K. H., \& Demetris, V. (2012). Brand emotional connection and loyalty. Journal of Brand Management, 20(1), 13-27.

Machado, J. C., Vacas-de-Carvalho, L., Azar, S. L., André, A. R., \& dos Santos, B. P. (2019). Brand gender and consumer-based brand equity on Facebook: The mediating role of consumer-brand engagement and brand love. Journal of Business Research, 96, 376-385.

Netemeyer, R. G., Bearden, W. O., \& Sharma, S. (2003). Scaling procedures: Issues and applications. Thousand Oaks: Sage Publications.

Oliver, R. L. (1980). A cognitive model of the antecedents and consequences of satisfaction decisions. Journal of marketing research, 17(4), 460-469.

Oliver, R. L. (1997). Satisfaction: A behavioral perspective on the consumer. New York: McGraw Hill.

Oliver, R. L. (1999). Whence consumer loyalty? The Journal of Marketing, 63(1), 33-44.

Oliver, R. L. (2014). Satisfaction, A behavioral perspective on the consumer. London: Routledge.

Palusuk, N., Koles, B., \& Hasan, R. (2019). 'All you need is brand love: A critical review and comprehensive conceptual framework for brand love. Journal of Marketing Management, 35(1-2), 97-129.

Pang, J., Tat, K. H., \& Peng, S. (2009). Effects of advertising strategy on consumer-brand relationships: A brand love perspective. Frontiers of Business Research in China, 3(4), 599-620.

Reichheld, F. F. (2003). The one number you need to grow. Harvard business review, 81(12), 46-55.

Ringle, C. M., Wende, S., \& Becker, J. M. (2015). SmartPLS 3. Hamburg. 
Rosado-Pinto, F., Loureiro, S. M. C., \& Bilro, R. G. (2020). How brand authenticity and consumer brand engagement can be expressed in reviews: A text mining approach. Journal of Promotion Management, 26(4), 457-480.

Rossiter, J. R. (2011a). Marketing measurement revolution. European Journal of Marketing.

Rossiter, J. R. (2011b). Rationale of C-OAR-SE. Measurement for the Social Sciences (pp. 1-11). New York: Springer.

Rossiter, J. R. (2012). A new C-OAR-SE-based content-valid and predictively valid measure that distinguishes brand love from brand liking. Marketing Letters, 23(3), 905-916.

Roy, S. K., Eshghi, A., \& Sarkar, A. (2013). Antecedents and consequences of brand love. Journal of Brand Management, 20(4), 325-332.

Sarkar, A., Ponnam, A., \& Murthy, B. K. (2012). Understanding and measuring romantic brand love. Journal of Customer Behaviour, 11(4),: 324-347.

Sarstedt, M., \& Mooi, E. (2019). A concise guide to market research (third). Germany: Springer.

Shaffer, J. A., DeGeest, D., \& Li, A. (2016). Tackling the problem of construct proliferation: A guide to assessing the discriminant validity of conceptually related constructs. Organizational Research Methods, 19(1), 80-110.

Thomson, M., MacInnis, D. J., \& Park, C. W. (2005). The ties that bind: Measuring the strength of consumers' emotional attachments to brands. Journal of Consumer Psychology, 15(1), 77-91.

Ting-Toomey, S. (1991). Intimacy expressions in three cultures: France, Japan, and the United States. International Journal of Intercultural Relations, 15(1), 29-46.

Usunier, J. C. (1998). International and cross-cultural management research, Sage.
Van Deursen, A. J., Bolle, C. L., Hegner, S. M., \& Kommers, P. A. (2015). Modeling habitual and addictive smartphone behavior: The role of smartphone usage types, emotional intelligence, social stress, self-regulation, age, and gender. Computers in Human Behavior, 45, 411-420.

Voorhees, C. M., Brady, M. K., Calantone, R., \& Ramirez, E. (2016). Discriminant validity testing in marketing: An analysis, causes for concern, and proposed remedies. Journal of the Academy of Marketing Science, 44(1), 119-134.

Wallace, E., Buil, I., \& de Chernatony, L. (2014). Consumer engagement with self-expressive brands: Brand love and WOM outcomes. Journal of Product \& Brand Management, 23(1), 33-42.

Witzel, A. (2000). The problem-centered interviews [26 paragraphs]. Forum Qualitative Sozialforschung / Forum: Qualitative Social Research, 1(1), 1.

Witzel, A., \& Reiter, H. (2012). The problem-centred interview: Principles and practice. London: SAGE Publications Ltd.

Yeh, C.-H., Wang, Y.-S., \& Yieh, K. (2016). Predicting smartphone brand loyalty: Consumer value and consumer-brand identification perspectives. International Journal of Information Management, 36(3), 245-257.

Yoo, B., \& Donthu, N. (2001). Developing and validating a multidimensional consumer-based brand equity scale. Journal of Business Research, 52(1): 1-14.

Yim, C. K., \& Kannan, P. (1999). Consumer behavioral loyalty. Journal of Business Research, 44(2), 75-92.

Zhao, X., Lynch Jr, J. G., \& Chen, Q. (2010). Reconsidering Baron and Kenny: Myths and truths about mediation analysis. Journal of Consumer Research, 37(2), 197-206. 